УДК 343.2.01

\title{
H. A. Opsовська
}

\section{СУДОВИЙ ПРЕЦЕДЕНТ ЯК ДЖЕРЕЛО КРИМІНАЛЬНОГО ПРАВА УКРАЇНИ}

У вітчизняній науці й доктрині кримінального права суттєво пожвавилися дискусії шодо концептуальних проблем джерел цієї галузі, шо $\epsilon$ відлунням загальнотеоретичних пошуків. Так, теоретики зазначають, шо спроби надання позитивному праву характеру «досконалого законодавства» (кодексу приписів), яке могло б охоплювати всі подробиші та передбачати всі можливі випалки, $є$ хибними. Закон неминуче залишається на рівні абстрактності та всезагальності. Відповідно, прихильники позитивізму відмовляються від розуміння закону, яке панувало в XIX столітті. Нині вони визнають правотворчу роль, а відтак і юридичну чинність договорів, доктрин і рішень суддів. За сучасних умов доводиться визнати, шо абсолютний суверенітет закону в країнах романо-германської правової сім'ї $\epsilon$ фікцією, поряд із ним існують також інші джерела права [1, с. 80, 85].

Вважаємо, шо ця позиція підтверджується не лише результатами впливу процесу глобалізаціі, за якого вілбувається уніфікація видів формальних юридичних джерел у всіх правових сім'ях, а й збільшенням активності «нових» суб'єктів правотворчості, зокрема інститутів громадянського суспільства. Якщо сучасне право має спрямовуватися насамперед на задоволення потреб людей, колективних суб'єктів і загалом суспільства, то не можна нівелювати формат правотворення «знизу - вгору». Відповідно, до нормативного акта (основного джерела, яке опосередковує формат правотворення «зверху - вниз») усе частіше додаються й інші джерела права, серед яких назвемо прецедент [2, с. 12-13], насамперед судовий.

Для «споживачів» кримінального права (сторін кримінально-правових конфліктів, держави) питання судового прецеденту пов'язуються з можливостями оперативного реагування на виклики сучасності, нівелювання нормативної нестійкості, підвишення рівня захисту прав і свобод та загалом реалізації принципу верховенства права, який не $\epsilon$ аб́страктним ідеальним конструктом, адже його слід наповнювати реальнім змістом. I це повинно стати завданням не лише законодавця, а й правозастосувагів. 
Саме на цьому наголошується у звіті Венеціанської комісії «Про верховенство права», прийнятому на 86 пленарному засіданні 25-26 березня 2011 р., у висновках конференції «Верховенство права як практичне поняття», проведеної Венеціанською комісією в співпраці з Міністерством закордонних справ Великої Британії та Центром верховенства права Бінгхема 2 березня $2012 \mathrm{p}$.

Інтерес до проблематики джерел кримінального права в цілому (у тому числі як складової загальної концепції джерел) і судового прецеденту зокрема виявляють як криміналісти, так і теоретики права: П.П. Андрушко, Ю.В. Баулін, А.Е. Жалінський, Д.В. Кирилюк, В.М. Кампо, О.Г. Кібальнік, М.І. Козюбра, В.О. Котюк, Д.В. Кухнюк, М.П. Куцевич, Л.А. Луць, Б.В. Малишев, М.І. Мельник, В.О. Навроцький, А.В. Наумов, К.В. Ображиєв, П.М. Рабинович, А.О. Селіванов, О.Ф. Скакун, М.І. Сірий, Ю.В. Трунцевський, В.М. Шаповал, С.В. Шевчук, Г.Г. Шмельова та інші.

Однак до сьогодні в навчальній літературі домінує традиційна позиція щодо Кримінального кодексу України (далі - КK України) як єдиного джерела кримінального права України, причому фахівці не лише формулюють, а й грунтовно розробляють проблематику багатоджерельності кримінального права.

У спеціальній літературі представлено концепцію поділу джерел права взагалі та кримінального права зокрема на матеріальні й формальні. Більше того, сучасні дослідники, наголошуючи на виявленні різних «шарів» буття права (соціального, ментального й формального), виокремлюють вілповідні їм матеріальні, ідеологічні та юридичні джерела [3, с. 258]. У шьому сенсі ідеологічним джерелом кримінального права може бути визнано соціальну практику в широкому сенсі цього слова, матеріальними джерелами - Конституцію України та міжнародно-правові договори, формальним (юридичним) джерелом - KK України, який відображає спосіб вираження й закріплення (форму) кримінально-правових норм. Однак такий підхід фактично приводить до твердження, шо КK України, грунтуючись на положеннях Конститушіi України та на загальновизнаних приншипах і нормах міжнародного права (ч. 1 ст. 3 KK України), визначає межі регулятивного значення Конституції України, міжнародно-правових договорів для кримінально-правового поля. Безперечно, це $\epsilon$ неправильним, адже саме Конституція України формує предметне поле (межі) кримінально-правового регулювання, визначаючи як найважливіші соціальні цінності, які доцільно поставити під охорону КК України, так і ті права й свободи людини та громадянина, шо можуть обмежуватися внаслідок вчинення злочину (адже покарання - це правообмеження).

Більш раціональним у цьому сенсі видається розгляд кримінального права як позитивного, тобто через систему формально-юридичних джерел [4, с. 27]. Відповідно, для кримінального права всі джерела є формальними (формально-юридичними).

Однак такий погляд вимагає диференціації джерела й форми кримінального права. Джерело характеризує «витік», походження норм, які регулю- 
ють відносини, шо становлять предмет кримінального права. У цьому плані принципового значення набуває характеристика суспільних відносин, ï важливість і специфіка, ајже якшо відповідні правові норми регулюють відносини, шо становлять предмет кримінального права, то їх слід визнати його джерелами. У свою чергу форма являє собою своєрідний «контейнер» цих норм, спосіб їх зовнішнього офіційно-документального вираження й закріплення.

Така диференціація дозволяє дійти висновку, що багатоджерельність кримінального права поєднується з одиничністю його форми. Формою кримінального права України може бути лише KK України. На наше переконання, особливості кримінально-правового впливу на окремі групи суб'єктів (наприклал, неповнолітніх, військових та інших) або специфіка реагування на певні види кримінальних правопорушень (кримінальні проступки) не потребують спеціальних законів (як, наприклад, у зарубіжних країнах). Відповідні інститути мають бути частиною єдиного кодифікованого законодавчого акта.

Однак KK України не можна розглядати лише як закон, що встановлюе злочинність, караність діяння та інші правові наслідки його вчинення (ч. 3 ст. 3). Зміст нормативних приписів KK України $є$ значно ширшим, адже в ньому представлено норми-завдання, норми-принципи, норми-дефініціі, суто регулятивні норми, які за способами регулювання класифікуються не лише на заборонні, а й зобов'язальні (у позитивному сенсі), заохочувальні та уповноважувальні.

Багато фахівців, зокрема й I.I. Митрофанов, вважають, шо слід розрізняти джерела кримінального права та джерела кримінального законодавства. У цьому сенсі пропонується говорити про багатоджерельність саме кримінального права. Вважаємо, що такий підхід є певною мірою рудиментом радянської правової думки, коли єдиним власне джерелом права вважався нормативний акт, відповідно, питання джерел права витіснялися дискурсом про співвідношення системи права й системи законодавства, особливо в кримінально-правовій плошині. Крім шього, вбачається, шо диференціація джерел і форм кримінального права загалом дозволяє вибудовувати сучасну концепцію останнього.

У контексті джерел поряд із КK України можна наводити також судовий прецедент. Вважаємо, що традиційна позиція щодо того, що судовий прецедент не $\epsilon$ джерелом права, оскільки суди не $\epsilon$ правотворчими органами, а рішення вищих судових інстанцій виступають лише орієнтирами для правильного розуміння й застосування норм права (судові рішення як інтерпретаційні акти), на сьогоџні потребує уточнення.

Судовий прецедент - це результат відправлення правосуддя вищими судовими інстанціями; це акт, у якому суд, піддаючи тлумаченню та роз'яснюючи нормативно-правові приписи, формулюе правила їх застосування, шо $є$ обов'язковими під час вирішення аналогічних справ.

Можна виокремити низку характерних ознак, притаманних сучасному розумінню судового прецеденту: 
- продукування прецеденту пише вишими судовими інстанціями або судами, єдиними у своєму роді;

- нормативний та загальнообов'язковий характер прецеденту як для судів нижчих інстанцій, так і для всіх інших державних органів і посадових осіб;

- певна зв'язаність судових інстанцій, які продукують прецеденти, власними рішеннями;

- оприлюднення судових рішень прецедентного характеру в бюлетенях або інших офіційних виданнях, і в цьому сенсі - писаний характер прецеденту;

- формування й функціонування прецеденту на основі чинного законодавства;

- спрямованість прецедентів не лише на більш ефективний і кваліфікований розгляд судами конкретних справ, а й на ліквідацію пробілів у праві та однакове тлумачення оцінних понять у законах та інших нормативно-правових актах.

3 огляду на це в контексті проблематики джерел кримінального права можна дискутувати щодо прецедентності рішень Конституційного Суду України, Верховного Суду України, Европейського суду з прав людини.

Конституційний Суд України (Јалі - KCУ) є єдиним органом конституційної юрисдикції. Шодо природи його рішень (процесуальних актів, які ухвалюються з питань конституційності законів та інших правових актів, офіційного тлумачення Конститушіі України та законів України) було виокремлено декілька концептуальних підходів [5, с. 101], серед яких $\epsilon$ принципово протилежні:

- рішення й висновки КСУ не існують самостійно та можуть враховуватися лише в процесі нормозастосування щодо положень Конституції України й законів (В.М. Шаповал $[6$, с. 29]);

- рішення KCУ, якими визнано закони, інші нормативно-правові акти або ї окремі положення неконституційними, мають силу нормативно-правового акта, адже вони породжують нові права й обов'язки; фактично КСУ виконує функцію негативного правотворця (В.П. Тихий $[7$, с. 29]).

Звернемо увагу, шо відповідно до ст. 8 Конституції України іiі норми мають найвишу юридичну силу та $є$ нормами прямої діi. Тому для захисту конституційних прав і свобод людини й громадянина гарантується звернення до суду безпосередньо на підставі Конституції України. Для дотримання цього положення ще в 1996 р. Пленум Верховного Суду України прийняв Постанову «Про застосування Конституції України при здійсненні правосуддя» за № 9, яка зобов'язує суди під час розгляду конкретних справ в усіх необхідних випадках застосовувати Конституцію України як акт прямої дії [8]. Однак при шьому питання шодо тлумачення Конститушії України та конституційності/неконституційності нормативно-правових актів $€$ виключною компетенцією КСУ. Згідно із цим можна дійти висновку, що застосування положень Конституції України відбувається з урахуванням правових позицій КСУ. 
На нашу думку, має рацію Ю.В. Баулін, зазначивши, шо своєю діяльністю КСУ як гарант верховенства Основного Закону України на території нашої держави не лише сприяє у формі конституційного судового контролю становленню та розвитку кримінального законодавства, а й де-факто $\epsilon$ одним із креативних учасників ших прошесів [9, с. 23].

Як зазначається в ч. 2 ст. 152 Конституції України, закони, інші правові акти або їх окремі положення, які визнано неконституційними, втрачають чинність із дня ухвалення КСУ рішення про їх неконституційність. При цьому рішення КСУ не підлягають оскарженню. Інакше кажучи, акти КСУ відрізняються від класичної правової норми за структурою, механізмом прийняття й набрання чинності, відповідно, їх не можна вважати традиційними нормативно-правовими актами $[10$, с. 151]. За своєю правовою природою вони є спешифічним Јжерелом права. Іх специфічність полягає в тому, шо ці правові позишії формулюються під час здійснення судового конституційного контролю, який за своє правовою природою не $\varepsilon$ нормотворчою діяльністю $[9$, с. 24].

На наше переконання, рішення КСУ є прецедентом, який відповідає всім виокремленим ознакам сучасного прецеденту. Правова природа таких рішень $є$ подвійною: це не лише обов'язковий прецедент тлумачення, а й нормативний прецедент, адже він може змінювати обсяг правової регламентації в будь-якій правовій сфері. Тому вважаємо, шо рішення КСУ як судові прецеденти є джерелом кримінального права

Шодо правових позицій Верховного Суду України теоретики права, зокрема О.Ф. Скакун, допускають, шо деталізація правових норм у них сприяє створенню нових правовідносин не лише правозастосовного, а й нормативного характеру. Крім того, будь-які судові рішення, які грунтуються на аналогії закону чи на загальних принципах права, можуть сприйматися судами після проходження рішення через касаційну інстанцію як фактичний прецедент [11, с. 332]. У свою чергу А.Б. Венгеров писав, шо вищий орган судової системи розкриває в конкретних рішеннях оціночні поняття, таким чином конкретизуючи й деталізуючи закон. Відповідні рішення стають правоположеннями, які набувають обов'язкового характеру, забезпечуються авторитетом вишого судового органу, його здатністю відміняти всі ті рішення, що суперечать цим правоположенням [12, с. 420].

Слід зазначити, що вітчизняний законодавець певною мірою визначив свою позицію: ст. 458 Кримінального процесуального кодексу України (далі - КПК України) містить прямий припис щодо обов'язковості судових рішень Верховного Суду України в частині того, «як саме має застосовуватися відповідна норма закону України про кримінальну відповідальність шодо подібних суспільно небезпечних діянь» (ч. 2 ст. 455 , ч. 2 ст. $456 \mathrm{KПK}$ України). У шьому разі не йдеться про аналогію закону, адже на це є пряма заборона - ч. 4 ст. $3 \mathrm{KK}$ України.

Вважаємо, шо судові рішення Верховного Суду України в зазначеній у КПК України площині - це обов'язковий прецедент тлумачення, що фактично утворює правила правозастосування. Однак останні $є$ невід'ємною 
частиною кримінально-правового регулювання, зокрема, вони становлять значний масив норм у Загальній частині KK Украйни (зобов'язальні приписи).

На нашу думку, позиція А.Б. Венгерова може слугувати теоретико-правовим підгрунтям розуміння значення цих рішень як джерела кримінального права України, при цьому такі обов'язкові прецеденти тлумачення містять певні елементи новизни, адже вони сприяють тому, щоб неправильне розуміння й застосування КK України судами не перетворилося на гальмо розвитку юридичної практики. Крім цього, судові рішення Верховного Суду України в площині, визначеній КПК України, відповідають тим ознакам, які притаманні сучасним судовим прецедентам.

3 огляду на це спірною вважаємо думку I.І. Митрофанова про хибність пропозичій шодо розгляду Верховного Суду України як регулюючої та стабілізуючої ланки в судовій системі. Скептицизм шодо шього, аргументований тим, що більшість спорів вирішується в нижчих інстанціях, а Верховний Суд України приймає для перегляду судові рішення, що набрали законної сили, не $\epsilon$ виправданим. Якщо судова практика відрізняється нестійкістю й суперечливістю, якшо суди часто займають діаметрально протилежні правові позиції шодо одного й того ж питання, хіба не Верховний Суд України мав би нівелювати таку ситуацію?

Особливе місце в дискурсі шодо судового прецеденту як джерела кримінального права посідає питання шодо рішень Європейського суду з прав людини (далі - ЄСПЛ).

Відповідно до ст. 1 Закону України «Про ратифікацію Конвенції про захист прав людини й основоположних свобод 1950 р., Першого протоколу та протоколів № 2, 4, 7 та 11 до Конвенціі» Україна визнала обов'язковою та без укладення спеціальної угоди юрисдикцію ЄСПЛ в усіх питаннях, що стосуються тлумачення й застосування Конвенції про захист прав людини й основоположних свобод від 4 листопада 1950 р. На підставі ст. 17 Закону України «Про виконання рішень та застосування практики Європейського суду з прав людини» суди застосовують піл час розгляду справ Конвенцію про захист прав людини й основоположних свобод та практику ЄСПЛ як джерело права. Цей прямий припис не містить будь-яких галузевих винятків. Норми Конвенції про захист прав людини й основоположних свобод мають узагальнене формулювання, тому рішення ЄСПЛ $є$ надзвичайно важливими в аспекті конкретизації ії положень. Крім того, принципові позиції, викладені, зокрема, у «моделтьни рішеннях» ЄСПЛ, $є$ вирішальними під час застосування норм Конвенції про захист прав людини й основоположних свобод [13, с. 307].

Чи означає таке рішення визнання ССПЛ судом вищої інстанції шодо судів національної юрисдикції? У шьому разі можна говорити про інтерпреташію інстанційноі підсудності: ЄСПЛ «Підключається» до рішення проблеми захисту прав і свобод людини лише після вичерпання всіх можливостей національної судової системи, а його рішення, відповідно до ст. 46 Конвенції про захист прав людини й основоположних свобод, ч. 1 ст. 2 
Закону України «Про виконання рішень та застосування практики Європейського суду з прав людини», є обов'язковими для України.

Тому не можна погодитися з тим, шо рішення ЄСПЛ в Україні мають силу переконливого прешеденту [13, с. 309-310]. Вважаємо, шо вони становлять обов'язковий прецедент тлумачення, за природою подібний до рішень Верховного Суду України, і в цьому сенсі можуть розглядатися як джерельна база кримінального права.

У цьому аспекті ще раз звернемо увагу на те, що обов'язкові прецеденти тлумачення, як уже зазначалося, містять значну частку нових правоположень, відповідно, у них наявна складова правотворчості. Для рішень ЄСПЛ це притаманно ше більшою мірою, ніж для судових рішень Верховного Суду України. Зокрема, як зазначає П.М. Рабинович, ЕСПЛ під час застосування Конвенції про захист прав людини й основоположних свобод акцентує увагу на можливості задовольняти певні потреби та інтереси насамперед людини, а також окремих людських спільнот, об'єднань і суспільства в цілому. При цьому ЄСПЛ постійно наголошує на необхідності зважати на специфічність, неповторність конкретної ситуації в різних державах, якщо вирішується питання про дотримання чи порушення певного права, про правомірність чи неправомірність у конкретній ситуації «поведінки» держави-відповідача. Конвенція про захист прав людини й основоположних свобод тлумачиться обов'язково у світлі актуальних умов сьогодення, тобто тих, які існують саме на момент розгляду відповідної справи. ЄСПЛ виходить із того, шо завжди буде існувати необхідність у пристосуванні загальних положень Конвенції про захист прав людини й основоположних свобод до змінюваних обставин $[14$, с. 9-10].

Однак виникає принципове питання щодо автономного тлумачення. Як відомо, автономне тлумачення полягає в тому, що ССПЛ не вважає обов'язковим для себе те значення, яке певний термін має в межах правової системи окремої держави, шо є стороною Конвенції про захист прав людини й основоположних свобод. Щодо проблематики, яка розглядається, прикладами можуть бути справи «Гурепка проти України», «Надточій проти України, «Корнєв і Карпенко проти України», у яких термін «кримінальне правопорушення» ССПЛ застосував до адміністративних і митних деліктів. При шьому ССПЛ виходив із таких обставин, як суворість правообмежень, яким було піддано особу («у силу суворості санкцій ця справа $є$ кримінальною» («Гурепка проти України»), йшлося про адміністративний арешт терміном 7 діб), як системний зв'язок митного й кримінального права («у силу пов'язаності між собою митних та кримінальних правопорушень ця справа $€$ кримінальною» («Надточій проти України»)). Відповідно, у разі застосування стягнень, які розглядаються як «кримінальні покарання» (наприклад, адміністративний арешт, конфіскація, значні суми штрафів тошо), провадження шодо накладення цих стягнень можуть вважатися «кримінальними» незалежно від формальної класифікашії в національному законодавстві $[15$, с. 165, 166].

Чи можна з огляду на це вважати, що ЄСПЛ суттєво розширив межі кримінально-правового регулювання як щодо кола правовідносин, що мо- 
жуть бути об'єктами кримінально-правової охорони / об'єктами злочинів, так і шоло кола покарань? На наше переконання, ні. Акцент було зробллено на захисті прав людини та її основоположних свобод у тих сферах, які межують із кримінально-правовою за характером суспільної небезпечності правопорушень і суворістю правообмежень. Саме через наближеність до кримінально-правового регулювання, до способів кримінально-правового впливу в зазначених галузевих площинах особа, винна у вчиненні відповідних правопорушень, потребує додаткового захисту. Інакше кажучи, у наведених випадках рішення ЄСПЛ входять у джерельну базу адміністративного й митного, проте не кримінального права.

Таким чином, у сучасному кримінально-правовому дискурсі вважаємо за доцільне наголосити, шо КK України - це є ина форма кримінального права, проте лише одне з його джерел. Серед останніх чільне місце слід відвести судовому прешеденту. Як судові прецеденти допустимо розглядати рішення КСУ, Верховного Суду України, ЄСПЛ.

Загалом поступове зростання значення судового прецеденту як джерела права обумовлюється збільшенням швидкості розвитку соціальних процесів, унаслідок чого законодавець не встигає врегульовувати нові суспільні відносини. У цьому плані кримінальне право не є винятком, тому можна прогнозувати остаточне визнання судового прецеденту джерелом кримінального права та розширення можливостей його застосування в цій сфері, хоча, зрозуміло, він поступатиметься КK України як єдиному законодавчому акту.

Загалом же розвідки шодо джерел кримінального права та вироблення сучасної позиції щодо місця джерел кримінального права в системі джерел права в цілому $є$ перспективним напрямом загальнотеоретичних і галузевих досліджень.

\section{Лiтература}

1. Дудченко В.В. Плюралістична теорія джерел права: нові можлнвості в осягненні права / В.В. Дудченко // Наукові праці Національного університету «Одесыка юрнднчна академія» / за ред. С.В. Ківалова. - О. : Кридична література, 2010. - Т. 9. - С. 78-88.

2. Сильченко Н.В. Проблемы типологии источников белорусского права / Н.В. Сильченко // Вісник Запорізького національного університету. Серія «Юридичні науки». - 2013. - ㄴo 1. - Вип. 2. - C. 11-18.

3. Тіщенко Ю.В. Форми міфу у правовій реальності / Ю.В. Тіщенко // Науковнй вісник Ужгородського національного універснтету. Серія «Право». - 20І3. - Внп. 23. - Ч. 1. - Т. 3. - C. 258-261.

4. Богачев В.В. Глобализация права : автореф. дисс. ... докт. юрид. наук : спец. 12.00 .01 «Теория и история права и государства; история учений о праве и государстве» / В.В. Богачев ; ФКОУ ВПО «Владимнрский юрндическнй ннстнтут Федеральной службы нсполнення наказаннй». - Владимир, 2012. - 48 с.

5. Кампо В.М. Легітимність рішень конституційних судів у гонтексті доктрини верховенства права: компаративістський та праксеологічний аспекти В.М. Кампо, М.В. Савчин // Вісник Конституційного Суду України. - 2010. - ⿺․ 5. - С. 99-109.

6. Шаповал В.М. Становлення конституціоналізму в Україні: проблеми теорії / В.М. Шапова.л // Право України. - 1998. - o 5. - С. 25-29. 
7. Тихий В.П. Правова природа, повноваження, рішення та висновки Конституційного Суду України / В.П. Тихий // Право України. - 2010. - № 6. - С. 26-32.

8. Про застосування Констнтуції Українн прн здійсненні правосуддя : Постанова Пленуму Верховного Суду України від 1 листопада 1996 р. № 9 [Електронний ресурс]. - Режим доступу : http:/ / zakon2.rada.gov.ua/laws/show/v0009700-96.

9. Баулін Ю.В. Вплив рішень Конституційного Суду Уираӥни на розвиток конституційної доктрини в галузі кримінального та кримінального процесуального права / Ю.В. Баулін / / Вісник Південного регіонального центру Національної академії правових наук Укра. їни. - 2014. - Jo 1. - C. 16-24.

10. Астрова Л.М. Рішення Конституційного Суду в системі права України / Л.М. Астрова / / Вісник Академії адвокатури України. - 2013. - № 2. - С. 148-152.

11. Скакун О.Ф. Теорія держави і права : Ппідручник] / О.Ф. Скакун. - пер. з рос. - X. : Kонсум, 2001. $-656 \mathrm{c}$.

12. Венгеров А.Б. Теорня государства н права : |учебник для юрнд. вузов] / А.Б. Венге. ров. - З-е изд. - М. : Новый юрист, 1998. - 624 с.

13. Задирака Н.К). Правова природа рішень Європейського суду з прав людини як джерел адміністративно-процесуального права України / Н.Ю. Задирака, К.О. Скічко // Юридичний вісник. - 2014. - 니 2. - С. 306-311.

14. Рабнновнч П.М. Потребове праворозуміння як внслід соціально-матеріалістнчної параднгмн (загальнотеоретична характеристика) / П.М. Рабинович / / Вісник Південного регіонального центру Національної академії правових наук України. - 2014. - № 1. - С. 6-15.

15. Фулей T.1. Значення автономного тлумачення понять Європейським судом з прав людини для правової системи України / T.І. Фулей // Вісник Академії адвокатури України. -2013 . № 2. - C. 164-167.

\section{Анота ція}

Орловська H. A. Судовий прецедент як джерело кримінального права України. - Стаття.

Статтю присвячено питанню шодо судового прецеденту як джерела кримінального права. Акцентовано увагу на рішеннях Конституційного Суду України, Европейського суду з прав людини, Верховного Суду України.

Клочові слова: кримінальне право, джерела, судовий прецедент.

\section{Аннотация}

Opsosckar H. A. Судебный прецедент как источник уголовного права Украины. - Статья.

Статья посвяшена вопросу о судебном прецеденте как источнике уголовного права. Акцентируется внимание на решениях Конституционного Суда Украины, Европейского суда по правам человека, Верховного Суда Украины.

Клюневые слова: уголовное право, источники, судебный прецедент.

\section{S u m m a r y}

Orlooska $\boldsymbol{N}$. A. Judicial precedent as Ukraine criminal law source. - Article.

The article is devoted to judicial precedent as a criminal law source problem. The attention to the Constitutional Court of Ukraine. European Court of Human Rights and Supreme Court of Ukraine decisions is accented.

Key words: criminal law, sources, judicial precedent. 